both the Society of Arts and the Royal Society, attending many committee meetings of the former and serving four times on the Council of the latter. A Franklin Commemorative Medal was presented to the Royal Society of Arts during the meeting.

Franklin was a member of many other scientific societies, including the Royal Society of Edinburgh. At a meeting held in the rooms of this Society on January 16, lectures were given by Prof. A. D. Ritchie, profossor of philosophy in the University of Edinburgh, and Dr. W. P. D. Wightman, reader in the history and philosophy of science in the University of Aberdeen, on "Franklin's Political Career and Philosophical Outlook" and "Franklin as a Natural Philosopher", respectively. Both lecturers commented on Franklin's wide interests and great gifts. When ho visited Edinburgh in 1759, he was made a burgess by the Town Council, and became a member of the Philosophical Society, the forerunner of the Royal Society of Edinburgh itself. The latter Society elected him as one of its first honorary fellows. The meeting opened with the presentation by Mr. E. D. Kuppinger, American Consul-General in Edinburgh, of a Franklin Commemorative Medal to the Society.

\section{Geological Society of London: Awards for 1956}

THE Geological Society of London has made the following awards for 1956: Wollaston Medal, to Prof. Arthur Holmes, professor of geology in the University of Edinburgh, for his world-wide interests in petrology and petrogenesis and the application of radioactivity to the problem of geological time; Murchison Medal, to Dr. F. M. Trotter, assistant director of H.M. Geological Survey, for his studies of the structure and stratigraphy of the Carboniferous rocks of England and Wales, especially in relation to coal and iron; Lyell Medal, to Dr. L. R. Cox, of the British Museum (Natural History), for his palæontological researches, especially on the Mesozoic and Tertiary molluses; Wollaston Fund, to W. B. Harland, of the University of Cambridge, for his researches on the structure and stratigraphy of Spitsbergen; Murchison Fund, to Dr. W. W. Black, of the University of Cambridge, for his research work on'the sedimentation and contemporaneous structures of the Carboniferous Limestone; Lyell Fund, a moiety to Dr. W. S. Pitcher, of King's College, London, for his researches on the igneous and metamorphic rocks of Donegal and on the Tertiary and Pleistocene deposits of south-east England, and another moiety to H. R. Tainsh, chief geologist of the Burmah Oil Company, for his researches on the geology and oil resources of Burma.

\section{Two New Research Reactors at Harwell}

THe United Kingdom Atomic Energy Authority has announced that two new reactors (or atomic piles) are now operating at Harwell--ZEUS (zeroenergy uranium system) and ZETR (zero-energy thermal reactor)-both of which are for research purposes only and run at very low power-levels. ZEUS has a cylindrical core, roughly $20 \mathrm{in}$. in diameter and $20 \mathrm{in}$. long, which is made of uranium very highly enriched in the rare isotope uranium-235; the enriching was carried out at the Atomic Energy Authority's factory at Capenhurst, near Chester. The core is surrounded by many tons of uranium in which plutonium is formed gradually as the pile runs. The very low power-level of $100 \mathrm{~W}$. at which the reactor is operated is such that no cooling is required, although the rate of the nuclear reaction is adequate for making experimental measurements. It has been built to check the nuclear calculations on which depends the design of the fast reactor of about $60 \mathrm{MW}$. which is being built at Dounreay in the north of Scotland, and in many essentials it is a full-scale version of the Dounreay reactor. The other research reactor, ZETR, uses a nuclear fuel in solution and is intended to provide information about the quantities of fuel which will be required for large-scale reactors using such solutions. Plutonium has already been studied in this reactor; uranium-235 is being studied now and uranium-233 is to be studied later this year. Natural water is used as a solvent at present; but in the summer heavy water is to be used.

\section{The Derbyshire Earth Tremor of January 10}

As earth tremor, accompanied by a low rumbling sound, occurred in Derbyshire on January 10 and was felt in many places in Derbyshire, Leicestershire, Rutland and Nottinghamshire. Up to a distance of some ten miles from the epicentre, windows and crockery rattled, and cases occurred of beds moving and pictures falling from walls. At Woodhouse Eaves in Leicestershire, the tremor appeared to come from the north. The shock was reported from Derby, Leicester, Nottingham; Burton-on-Trent, Ashton-onTrent, Melton Mowbray, Rothley, Coalville, Heanor and Castle Donington. It was recorded on the Milne-Shaw horizontal seismograph at Bidston Observatory, near Liverpool, at $08 \mathrm{~h} .12 \mathrm{~m}$. 14s. G.M.T., and on the short-period vertical seismograph (made at Kew) at Kew at $08 \mathrm{~h} .12 \mathrm{~m}$. 21s. G.M.T. The shock was also recorded at Durham University Observatory and at Rathfarnham Castle, Dublin. It was just recorded at the Royal Observatory at Edinburgh, but not at Aberdeen. From the readings it appears that the epicentre was to the south-east of Derby (near $52^{\circ} 50^{\prime} \mathrm{N} ., 1^{\circ} 25^{\prime} \mathrm{W}$. ), and the initial time was $08 \mathrm{~h} .11 \mathrm{~m}$. 5ls. G.M.T.; the depth of focus was probably about 12 or $13 \mathrm{~km}$. There may have been an aftershock from the same district a little after 10 a.m. ; but the recording of this is doubtful owing to microseisms, and also waves arriving from an earthquake in the Pacific.

The earliest earthquake noted from Derbyshire occurred in the year 1084, and there were furthor earthquakes in November 1678; October 31, 1734; July 10, 1738; and June 26, 1748; but the largest shock was on November 18, 1795, about 11.10 p.m. On that occasion, chimneys were thrown down at Derby, Nottingham and Ashover, and the shock was felt as far away as York, Liverpool, Bristol, London and Norwich. A shock with its epicentre four miles south-east of Derby was felt on November 13, 1872, about 4.10 p.m. Earth tremors occurred at Winster in Derbyshire in 1952. That of February 22 at $9.20 \mathrm{a} . \mathrm{m}$. had intensity VI on the Modified Mercalli Scale. More feeble shocks occurred on February 24, March 17 and two on April 15. The tremors in 1952 were probably due to geological fault adjustments along the branch faults which are a continuation of the Crich-Cromford-Bonsall fault belt. A further slight tremor occurred at Winster on November 15, 1954. The shock rattled doors, windows and crockery, and a crump-like sound preceded the tremor.

\section{Royal Society and Nuffield Foundation Common- wealth Awards}

Awards under the Royal Society and Nuffield Foundation Commonwealth bursaries scheme have 